Article Code: 0225/2019/RALF

Res. Agric. Livest. Fish.

Article Type: Original Research

Vol. 6, No. 2, August 2019 : 163-169.

\title{
VARIABILITY, HERITABILITY AND GENETIC ADVANCE OF MAIZE (Zea mays L.) GENOTYPES
}

\section{Sampurna Bartaula ${ }^{1 *}$, Urbashi Panthi ${ }^{1}$, Kiran Timilsena ${ }^{2}$, Subarna Sharma Acharya ${ }^{3}$ and Jiban Shrestha ${ }^{4}$}

${ }^{1}$ Institute of Agriculture and Animal Science, Prithu Technical College, Tribhuvan University, Nepal; 2Department of Plant Breeding, Tribhuvan University, Kirtipur, Nepal; ${ }^{3}$ Institute of Agriculture and Animal Science, Lamjung Campus, Tribhuvan University, Nepal; ${ }^{4}$ Nepal Agricultural Research Council, Agriculture Botany Division, Khumaltar, Lalitpur, Nepal.

*Corresponding author: Sampurna Bartaula; E-mail: agsampurna@gmail.com

\section{ARTICLE INFO A B S T R A C T}

Received

03 August, 2019

Revised

25 August, 2019

Accepted

27 August, 2019

Online

31 August, 2019

Key words

Maize

Grain yield

Variability

Heritability

Genetic advance
The selection efficiency for certain traits in crops can be broadened using estimates of genetic parameters, which are fundamental for plant breeding. Ten maize genotypes were evaluated in randomized complete block design (RCBD) with three replications at the field of Lamahi Municipality, Dang district of Nepal to assess the magnitude of genetic variability, heritability and genetic advance for growth, yield and yield contributing traits during summer season (June to August), 2018. Analysis of variance revealed significant differences for all traits. The phenotypic coefficient of variation (PCV) was higher than genotypic coefficient of variation (GCV) recorded for all traits. The grain yield showed the highest PCV (50.78\%) and GCV (51.24\%) whereas the lowest PCV (4.51\%) and GCV $(4.50 \%)$ were recorded for test weight; test weight showed high heritability $(0.99)$ with low genetic advance as a percent of mean (9.26). Grain yield showed positive and significant phenotypic correlation with test weight $(r=0.960)$, kernel per row $(r=0.924)$, kernel rows per cob $(r=0.900)$ and cob length $(r=0.840)$, respectively. Traits namely grain yield, number of kernels per cob and kernel rows per cob showed high GCV, PCV. Therefore these traits can be used further in crop improvement program.

To cite this article: Bartaula S, U Panthi, K Timilsena, SS Acharya and J Shrestha, 2019. Variability, heritability and genetic advance of maize (Zea mays L.) genotypes. Res. Agric. Livest. Fish. 6 (2): 163-169.

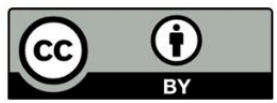




\section{INTRODUCTION}

Maize (Zea mays L.) is the most important cereal crops next to wheat and rice. It is the second most important cereal crop in terms of area, production and productivity after rice in Nepal. In Nepal, it is grown in $8,91,583$ ha producing 2.2 million tons, with an average yield of $2.5 \mathrm{t} / \mathrm{ha}$ (MOAD, 2016). The trend of production is increasing due to its wide range of utilization. In Nepal, maize is cultivated throughout the country. Maize acreage and production have an increasing tendency with the introduction of hybrids due to its high yield potential. It possesses one of the most well studied genetic systems among cereals which have motivated a rich history of research into the genetics of various traits in maize. It offers tremendous scope for the plant breeders for genetic improvement.

Selection is the basic step of breeding program. Selection of the best suitable variety in accordance to the existing environment determines the performance of each genotype. The efficiency of selection depends on the direction and magnitude of association between yield and its components. The efficiency of selection can be using estimates of genetic parameters, which are fundamental in the plant breeding, since they allow identifying the nature of the action of genes involved in the control of quantitative traits and evaluate the efficiency of different breeding strategies to obtain genetic gains (Vashistha et al., 2013). The estimates of genetic parameters as variances, coefficients of variation, heritability, genotypic, phenotypic and environmental correlations, allow knowing the magnitude of the genetic variability of a population, and the selection gains. A critical analysis of genetic variability present in the germplasm of a crop and its estimation is a pre-requisite for initiating any crop improvement programme as well as adopting appropriate selection techniques (Sravanti et al., 2017). The knowledge of heritability enables the plant breeder to decide the course of selection procedure to be followed under a given situation (Li and Yang, 1985). The estimates of genetic parameters like heritability and genetic advance helps in predicting the gain under selection. Therefore, this study was undertaken to study the genetic variability, heritability and genetic advance among the maize genotypes for yield and yield contributing traits.

\section{MATERIALS AND METHODS}

\section{Experimental site}

This experiment was carried out in the field of Lamahi Municipality, Dang district in the Province number 5, inner Terai region of Nepal during the summer season, 2018. It was located at latitude of $28^{\circ} 7^{\prime} 0^{\prime \prime} \mathrm{N}$ latitude, longitude of $82^{\circ} 18^{\prime} 0^{\prime \prime} \mathrm{E}$ and $628 \mathrm{~m}$ altitude. The $\mathrm{PH}$ of the experimental site was slightly acidic and the texture of the soil was silt loam.

\section{Climatic observation}

The experimental site was situated in the sub-tropical climatic zone of Nepal. The area has sub- humid type of weather condition with cold winter, hot summer and distinct rainy season. There are three distinct seasons "namely rainy season (June-October), cool winter (November- February) and hot spring season (March- May).The climatic data was taken from meteorological station, Ghorahi, Dang. Data on maximum and minimum temperature and rainfall during cropping season were recorded (figure 1). Regarding to temperature, the average maximum and minimum temperature during cropping season ranged from $31.32^{\circ} \mathrm{C}$ to $23.32^{\circ} \mathrm{C}$ respectively. The highest maximum and minimum temperature was recorded in month of June 1 st and 2nd week and June $3^{\text {rd }}$ week. The total rainfall $134.38 \mathrm{~mm}$ was recorded during crop growing period (June to September) 2018. Maximum rainfall was recorded during June 1st week and rainfall fewer weeks were Sep $2^{\text {nd }}, 3^{\text {rd }}$ and $4^{\text {th }}$ week and July $3^{\text {rd }}$ week.

\section{Plant materials}

Ten maize genotypes namely Rampur Composite, Deuti, ZM-401, Rampur-4, Manakamana-3, Arun-4, TLBR_507f16, Manakamana-7, Arun-2 and Farmer's variety as a Local check variety were used in the experiment. Except Farmer's Variety, all nine genotypes were received from National Maize Research Program, Rampur, Chitwan, Nepal 


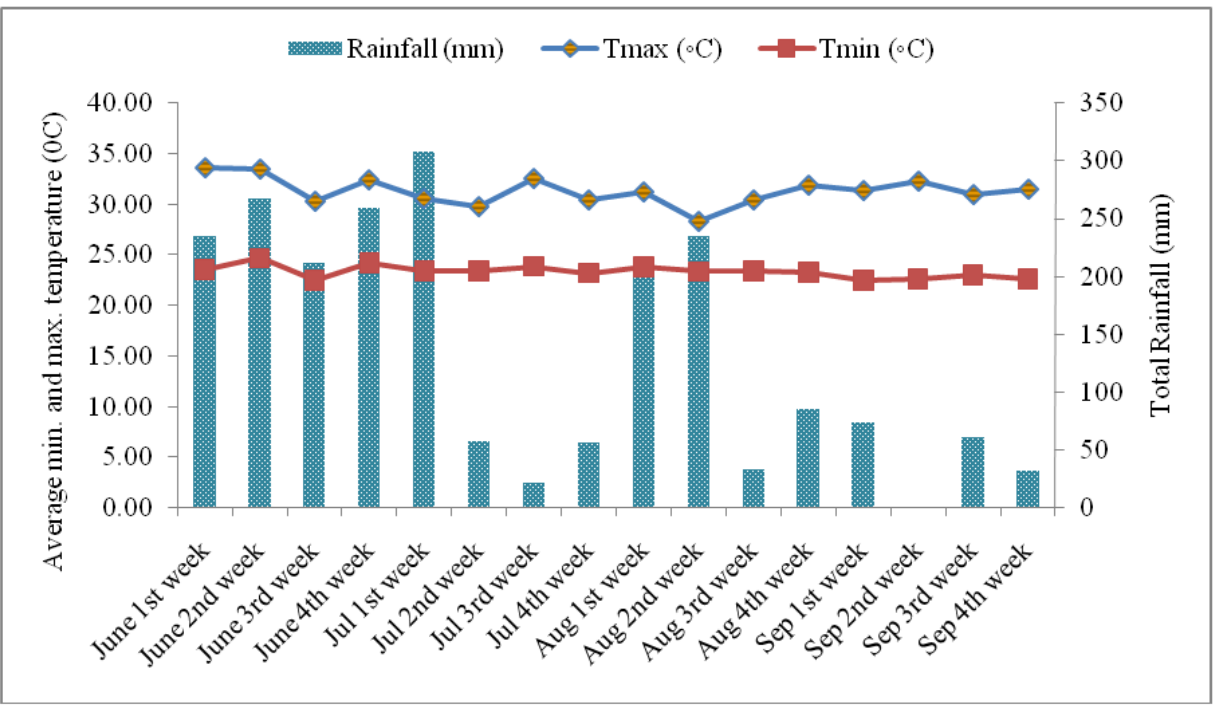

Figure1. Average weekly minimum and maximum temperature and total rainfall recorded at Ghorahi Meteorological station, Dang, Nepal from June to September, 2018.

\section{Experimental design and crop management}

The experiment was conducted in Randomized Complete Block Design (RCBD) with three replications. Each experimental plots were of size $6 \mathrm{~m}^{2}(2.4 \mathrm{~m} \times 2.5 \mathrm{~m})$ having 4 rows that were $60 \mathrm{~cm}$ apart. The seeds were sown on row $25 \mathrm{~cm}$ apart on June 03. The dose of chemical fertilizer applied was 120:60:40 kg NPK/ha. Fertilizer were applied prior to sowing at rate of $60 \mathrm{~N} \mathrm{~kg} / \mathrm{ha}, 60 \mathrm{~kg} \mathrm{P}$ and $40 \mathrm{~kg} \mathrm{~K} / \mathrm{ha}$ and additional side dressing of $30 \mathrm{~N} \mathrm{~kg} /$ ha were applied at the two times in six leaves stage and knee high stage of maize. The irrigation was done three important stage, knee high stage, tasseling stage and milking stage. Recommended package of practices was followed as per recommendation of National Maize Research Program, Rampur, Chitwan, Nepal.

\section{Data observation and analysis}

Observations were taken on randomly selected 10 plants from each experimental plot for all the traits under consideration. Grain yield was calculated using formula adopted by Carangal et al. (1971) and Shrestha et al. (2018) by adjusting the grain moisture at $15 \%$ and converted to the grain yield per hectare basis. The data collected on all the characters were subjected to standard methods of analysis of variance (Panse and Sukhatme, 1985). Phenotypic and genotypic coefficient of variation was calculated as suggested by Falconer (1981). Heritability (broad sense) (Johnson et al., 1955), genetic advance (Burton, 1952) and genetic advance as a percentof mean (Johnson et al., 1955) were also estimated.

\section{Statistical analysis}

All agronomic data from trials were analyzed by ANOVA using a split split-plot design. The experimental data were processed using Excel 2010 and analyzed by using Genestat software. Least significant difference (LSD $p \leq 0.05$ ) test was used for mean comparison to identify the significant components of the treatment means (Jan et al., 2009; Sharma et al., 2016; Gomez and Gomez, 1984). 


\section{RESULTS AND DISCUSSION}

\section{Genetic Variability}

The analysis of variance revealed the existence of significant differences among the genotypes for all the traits (Table 1), indicating the presence of considerable genetic variability among the experimental material under study. Thus, there is plenty of area and scope for improvement of different quantitative and qualitative traits through selection. Similar finding on presence of significant variability for various characters in the maize genotypes was also reported by many researchers in their study (Kumar et al., 2015; Kandel et al., 2018)

The mean values, genotypic and phenotypic coefficient of variation, heritability, genetic advance and genetic advance as percent of mean (Table 2) of all ten genotypes were calculated for yield and yield attributes. For all the characters under study except no. of leaves and cob length, phenotypic coefficient of variation values are slightly higher than the genotypic coefficient of variation values indicating that the characters were less influenced by the environment. Therefore, response to direct selection may be effective in improving these traits. In contrast to other traits, no. of leaves and cob length the difference between phenotypic coefficient of variation and genotypic coefficient of variation was higher indicating that the characters were more influenced by the environment. The characters studied in the present investigation exhibited low (less than 10\%), moderate (10-20\%) and high (more than 20\%) phenotypic and genotypic coefficients of variation. The estimates of phenotypic variation $(50.78 \%)$ and genotypic variation $(51.24 \%)$ were found to be high for grain yield $(\mathrm{kg} / \mathrm{ha})$. This findings was similar to the results were reported by Bhusal et al. (2017) and Sharma et al. (2018).

ASI (29.79\%, 27/11\%) and Kernel per cob (29.47\%, 28.88\%) reported high phenotypic and genotypic coefficients of variations. Results were supported by Kharel et al. (2017) who reported higher variability for kernel per cob and higher variability for ASI was reported by (Sharma et al., 2018). Plant height at harvest $(14.69 \%, 14.62 \%)$, ear height $(14.53 \%, 14.51 \%)$, kernel row per cob $(16.88 \%, 15.70 \%)$ and kernel per row $(13.84 \%, 13.59 \%)$ had moderate phenotypic and genotypic coefficients variations. These results were in conformity with the findings of Choudhary and Choudhary (2002) and Singh et al. (2003). Phenotypic and genotypic coefficients of variation were low for test weight $(4.51 \%, 4.50 \%)$. While traits namely No. of leaves $(11.19 \%, 6.31 \%)$ and Cob length (12.05\%, 8.82\%) expressed moderate PCV values coupled with low GCV values indicating high influence of environment on these characters.

\section{Heritability and genetic advance}

Seven characters under investigation viz., plant height at harvest (0.99), ASI (0.82), ear height (0.99), kernel row per cob (0.86) showed high estimates of heritability in broad sense. High heritability for these characters indicates the scope of genetic improvement of these characters through selection, which revealed that these characters are less influenced by environment and there could be greater correspondence between phenotypic and breeding values. Cob length (0.53) and no. of leaves (0.31) have moderate heritability. Ghimire and Timsina (2015) also reported higher heritability for ear height and grain yield.

Genetic advance as a percent of mean is classified as low (less than $10 \%)$, moderate (10-20\%) and high (more than $20 \%)$. Among the characters under study, no. of leaves (7.33\%) and test weight $(9.26 \%)$ exhibited low genetic advance as a percent of mean. Trait namely cob length (13.29\%) showed moderate genetic advance as a percent of mean. All other traits plant height (29.98\%, ASI (50.84\%), ear height (29.85\%), kernel row per cob (30.10\%), kernel per row (27.49\%), kernel per cob (58.32\%) and grain yield $(103.67 \%)$ showed high estimates of genetic advance as a percent of mean.

Among all the characters studied, test weight exhibited high heritability coupled with low genetic advance as a percent of mean suggesting expression of the trait is under the control of non-additive type of gene action, and its response to selection would be poor. In such case hybridization programme is rewarded. No. of leaves showed lower heritability as well as genetic advance suggesting the trait governance by non-additive gene action and direct selection would not be effective for the trait. All other traits under consideration expressed high heritability coupled with high genetic advance, which indicated the preponderance of additive gene action in controlling the traits. Hence direct selection of such characters would be effective in improving the yield. 
Table 1. Mean square comparison for different traits of ten maize genotypes at Lamahi, Dang, Nepal (2018)

\begin{tabular}{|c|c|c|c|}
\hline \multirow{2}{*}{ Parameters } & \multicolumn{3}{|c|}{ Mean Square of Squares } \\
\hline & Replication (df = 2) & Genotypes (df $=9$ ) & Error $(\mathrm{df}=18)$ \\
\hline Plant height at harvest $(\mathrm{cm})$ & 29 & $1055^{\star \star *}$ & 10 \\
\hline No. of leaves & 4.93 & 1.04 & 1.3 \\
\hline ASI (days) & 0.3 & $1.737^{\star \star \star}$ & 0.337 \\
\hline Ear height $(\mathrm{cm})$ & 0.1 & $301.9^{* * *}$ & 0.9 \\
\hline Cob length (cm) & 0.555 & 2.566 & 1.728 \\
\hline Kernel row per cob & 1.6 & $4.8^{\star * *}$ & 0.71 \\
\hline Kernel per row & 0.53 & $18.37^{\star \star \star}$ & 0.68 \\
\hline Kernel per cob & 2460 & $15541^{* * *}$ & 627 \\
\hline Test weight (g) & 0 & $125.2^{\star \star \star}$ & 0.5 \\
\hline Grain yield (kg/ha) & 35433 & $2833539^{* * *}$ & 51542 \\
\hline
\end{tabular}

Table 2. Variability, heritability and genetic advance for growth, yield and yield attributing traits of ten maize genotypes at Lamahi, Dang, Nepal (2018)

\begin{tabular}{|c|c|c|c|c|c|c|c|c|c|}
\hline Traits & $\sigma_{g}^{2}$ & $\sigma_{p}^{2}$ & $\sigma^{2}$ & Mean & GCV (\%) & PCV (\%) & Hbs & GA (\%) & GAM \\
\hline $\begin{array}{l}\text { Plant height at } \\
\text { harvest }(\mathrm{cm})\end{array}$ & 1051.67 & 10 & 1061.67 & 221.77 & 14.62 & 14.69 & 0.99 & 66.48 & 29.98 \\
\hline No. of leaves & 0.60 & 1.30 & 1.90667 & 12.333 & 6.31 & 11.19 & 0.31 & 0.90 & 7.33 \\
\hline ASI (days) & 1.62 & 0.33 & 1.96167 & 4.7 & 27.11 & 29.79 & 0.82 & 2.38 & 50.84 \\
\hline $\begin{array}{l}\text { Ear height } \\
(\mathrm{cm})\end{array}$ & 301.60 & 0.90 & 302.5 & 119.64 & 14.51 & 14.53 & 0.99 & 35.72 & 29.85 \\
\hline $\begin{array}{l}\text { Cob length } \\
(\mathrm{cm})\end{array}$ & 1.99 & 1.72 & 3.718 & 15.989 & 8.82 & 12.05 & 0.53 & 2.12 & 13.29 \\
\hline $\begin{array}{l}\text { Kernel row } \\
\text { per cob }\end{array}$ & 4.56 & 0.71 & 5.27333 & 13.6 & 15.70 & 16.88 & 0.86 & 4.09 & 30.10 \\
\hline $\begin{array}{l}\text { Kernel per } \\
\text { row }\end{array}$ & 18.14 & 0.68 & 18.8233 & 31.333 & 13.59 & 13.84 & 0.96 & 8.61 & 27.49 \\
\hline $\begin{array}{l}\text { Kernel per } \\
\text { cob }\end{array}$ & 15332 & 627 & 15959 & 428.67 & 28.88 & 29.47 & 0.96 & 250.01 & 58.32 \\
\hline $\begin{array}{l}\text { Test weight } \\
\text { (g) }\end{array}$ & 125.03 & 0.5 & 125.533 & 248.03 & 4.50 & 4.51 & 0.99 & 22.98 & 9.26 \\
\hline GY (kg/ha) & 2816358 & 51542 & 2867900 & 3304.4 & 50.78 & 51.24 & 0.98 & 3425.89 & 103.67 \\
\hline
\end{tabular}

$\sigma_{g}^{2}=$ Genotypic variance, $\sigma_{p}^{2}=$ Phenotypic variance and $\sigma^{2}{ }_{e}=$ Environmental variance, Hbs= Heritability broad sense, $\mathrm{GCV}=$ Genotypic coefficient of variation, $\mathrm{PCV}=$ Phenotypic coefficient of variation, $\mathrm{GA}=$ Genetic advance, GAM= Genetic advance as percent of mean. 


\section{Phenotypic correlation coefficients}

Estimates of phenotypic correlation of grain yield and other yield related traits are shown in Table 3. Grain yield showed positive and significant phenotypic correlation with test weight $(r=0.960)$, kernel per row $(r=0.924)$, kernel rows per cob $(r=0.900)$ and cob length $(r=0.840)$. Anthesis Silking interval showed highly significant negative correlation with yield $(r=-0.717)$ and Plant height showed moderately significant negative correlation $(r=-0.443)$ with grain yield. Correlations of grain yield with other traits considered were not significant. The most yield determinative traits were test weight followed by number of kernels per row and hence, simultaneous selection for these traits might bring an improvement in grain yield. Similar results were also obtained by Alvi et al. (2003), Prakash et al. (2006), Sreckov et al. (2010), Chinnadurai and Nagarajan (2011) and Kharel et al. (2017).

Table 3. Phenotypic correlation coefficient among different growth, yield and yield attributing traits of ten maize genotypes at Lamahi, Dang, Nepal (2018)

\begin{tabular}{|c|c|c|c|c|c|c|c|c|c|c|}
\hline Parameters & PH & $\begin{array}{l}\text { No. of } \\
\text { leaves }\end{array}$ & $\begin{array}{l}\text { ASI } \\
\text { (days) }\end{array}$ & EH & CL & RPC & KPR & KPC & TW & GY \\
\hline $\mathrm{PH}$ & 1 & 0.129 & $0.430^{*}$ & $0.726^{\star *}$ & $-0.434^{*}$ & $-0.445^{\star}$ & $-0.463^{* *}$ & -0.27 & $-0.492^{\star \star}$ & $-0.443^{*}$ \\
\hline $\begin{array}{l}\text { No. of } \\
\text { leaves }\end{array}$ & & 1 & -0.097 & 0.251 & 0.119 & 0.134 & 0.135 & 0.256 & 0.044 & 0.078 \\
\hline ASI (days) & & & 1 & 0.131 & $-0.650^{* *}$ & $-0.681^{* *}$ & $-0.709^{* *}$ & -0.181 & $-0.719^{\star *}$ & $-0.717^{* *}$ \\
\hline $\mathrm{EH}$ & & & & 1 & -0.223 & -0.248 & -0.24 & -0.166 & -0.308 & -0.325 \\
\hline CL & & & & & 1 & $0.739^{* *}$ & $0.950^{* *}$ & 0.193 & $0.826^{* *}$ & $0.840^{* *}$ \\
\hline RPC & & & & & & 1 & $0.911^{\star \star}$ & 0.075 & $0.924^{\star *}$ & $0.900^{\star \star}$ \\
\hline KPR & & & & & & & 1 & 0.159 & $0.926^{\star *}$ & $0.924^{\star \star}$ \\
\hline KPC & & & & & & & & 1 & 0.021 & 0.118 \\
\hline TW & & & & & & & & & 1 & $0.960^{\star *}$ \\
\hline GY & & & & & & & & & & 1 \\
\hline
\end{tabular}

${ }^{* *}$ Correlation is significant at the 0.01 level ${ }^{*}$. Correlation is significant at the 0.05 level. PH- Plant height at harvest $(\mathrm{cm})$, ASI- Anthesis Silking Interval, EH- Ear height $(\mathrm{cm}), \mathrm{CL}-\mathrm{Cob}$ length $(\mathrm{cm})$, RPC-Rows per cob, KPR-Kernel per row, KPCKernel per cob, TW-Test weight (gm) GY-Grain yield (kg/ha)

\section{CONCLUSION}

All the studied traits were significant, indicating that presence of genetic variability which can be exploited in crop improvement program. PCV is higher than GCV in all studied traits; it does indicate that there is no environmental influence. Traits namely grain yield, number of kernels per cob and kernel rows per cob having high GCV, PCV, heritability along with high genetic advance as percentage of mean were used in selection process of crop improvement program. As test weight, number of kernels per row and number of rows per cob were positively and highly correlated with grain yield hence, selection for these traits might bring an improvement in grain yield.

\section{ACKNOWLEDGEMENT}

The authors are grateful to Institute Of Agriculture And Animal Science, Prithu Technical College, Tribhuvan University, Nepal for providing research support and facilities for conducting this experiment. 


\section{CONFLICT OF INTESEST}

The authors declare that there is no conflict of interest.

\section{REFERENCES}

1. Alvi MB, M Rafique, M Shafique, A Hussain, $T$ Mohmood and M Sarwar, 2013. Characters association and path analysis of grain yieldand yield components in maize. Pakistan Journal of biological science, 6(2): 136-138.

2. Bhusal T, GM Lal, S Marker and GJ Synrem, 2017. Genetic variability and traits association in maize (Zea mays L.) genotypes. Annals of Plants and Soil Research, 19(1): 59-65

3. Burton GW, 1952. Quantitative inheritance in grasses. Proceedings of $6^{\text {th }}$ International Grassland Congress, 1: 277-283.

4. Carangal VR, SM Ali, AF Koble and EH Rinke, 1971. Comparison of S1 with testcross evaluation for recurrent selection in maize. Crop Science, 11: 658-661.

5. Chinnadurai IS and P Nagarajan, 2011. Interrelationship and path coefficient studies for qualitative traits, grain yield and other yield attributes among maize (Zea mays L.). International Journal of Plant Breeding and Genetics, 5(2): 1- 4 .

6. Choudhary AK and LB Chaudhary LB, 2002. Genetic studies in some crosses of maize (Zea mays L.). Journal of Research Birsa Agricultural University, 5 (1/2): 10-16

7. Falconer DS, 1981. Introduction to Quantitative Genetics. London: Oliver and Boyd.

8. Ghimire B and D Timsina, 2015. Analysis of Yield and Yield Attributing Traits of Maize Genotypes in Chitwan, Nepal. World Journal of Agricultural Research, 3(5): 153-162.

9. Gomez KA and AA Gomez, 1984. Statistical Procedures for Agricultural Research. John Wiley and Sons. New York. Pp. 680.

10. Jan MT, $P$ Shah, PA Hollington, MJ Khan and $Q$ Sohail, 2009. Agriculture research: Design and analysis. A monograph. Peshawar Agricultural University.

11. Johnson HW, HF Robinson and RE Comstock, 1955. Estimates of genetic and environmental variability in soybean. Agronomy Journal, 47: 314- 318.

12. Kandel BP, BK Sharma, S Sharma and J Shrestha, 2018. Genetic variability, heritability, and genetic advance estimates in early maize (Zea mays L.) genotypes in Nepal. Agricultura, 107(3-4): 29-35.

13. Kharel R, SK Ghimire, BR Ojha and KB Koirala, 2017. Estimation of genetic parameters, correlation and path coefficient analysis of different genotypes of maize (Zea mays L.). International Journal of Agriculture Innovations and Research, 6(1): 191-195.

14. Kumar M, R Singh and RP Srivastava, 2015. Screening genotypes for maize (Zea mays L.) for Eastern Uttar Pradesh conditions. International Journal of Applied Agricultural and Horticultural Sciences, 6(2): 237-240.

15. Li CM and KCYang, 1985. Studies on inheritance of quantitative characters for plant type in some inbred lines of maize. Scientia Agriculture Sinical, 9: 28-36.

16. MOAD, 2016. Statistical information on Nepalese agriculture.Agribusiness Promotion and statistics Division Singh Durbar, Kathmandu.Ministry of Government of Nepal.

17. Panse VG and PV Sukhatme, 1985. Statistical Methods for Agricultural Workers. New Delhi: ICAR.

18. Prakash O, P Shanthi, E Satyanarayana and KR Sai, 2006. Studies on inter relationship and path analysis for yield improvement in sweet corn genotypes (Zea mays L.). International Journal of Plant Science Research, 33: 1-4.

19. Sharma BK, S Sharma, BP Kandel and J Shrestha, 2018. Varietal evaluation of promising maize genotypes. Azarian Journal of Agriculture, 5(4): 120-124.

20. Sharma HP, KH Dhakal, R Kharel and J Shrestha, 2016. Estimation of heterosis in yield and yield attributing traits in single cross hybrids of maize. Journal of Maize Research and Development, 2(1): 123-132.

21. Shrestha J, DN Yadav, LP Amgain and JP Sharma, 2018. Effects of nitrogen and plant density on maize (Zea mays L.) phenology and grain yield. Current Agriculture Research Journal, 6(2): 175-182.

22. Singh $P, S$ Das, $Y$ Kumar, $Y$ Dutt and $O$ Sangwan, 2003. Variability studies for grain yield and its component traits in maize (Zea mays L.). Annals of Agri-Bio Research, 8: 2-31.

23. Sravanti K, I Swarnalatha Devi, MR Sudarshan and K Supriya, 2017. Evaluation of maize genotypes (Zea mays L.) for variability, heritability and genetic advance. International Journal of Current Microbiology and Applied Sciences, 6(10): 2227-2232.

24. Sreckov Z, J Bokanski, A Nastasic, I Alovic and M Vukosavljev, 2010. Correlation and path coefficient analysis of morphological traits of maize (Zea mays L.). Research Journal of Agricultural Science, 42(2): 292-296.

25. Vashistha A, NN Dixit, Dipika, SK Sharma and S Marker, 2013. Studies on heritability and genetic advance estimates in Maize genotypes. Bioscience Discovery, 4(2): 65-168. 